\title{
Sejarah Perkembangan Islam di Pulau Lombok pada Abad Ke-17
}

\author{
Basarudin \\ UIN Sunan Kalijaga
}

Naskah diterima 31 Agut 2018, direvisi 12 Sept 2018, disetujui 2 Des 2018

\begin{abstract}
This paper describes the history of the development of islam in Lombok in the 17 thcentury, showing that the island of Lombok is one of the places where Islam carried out by Sunan Prapen from East Java. The history of the spread of Islam is very interesting to study in the region bicause some buildings show that Islam has spread very quickly. Since Islam entered the Island of Lombok which began around the 17 th century AD was brought from South Sulawesi, and distributed through the island of Sumbawa. After the arrival of Islam the teachings have not been maximally applied on the island of Lombok. This can be seen in the development of Islamic teachings in Lima and the teachings of Islam of Telu Time until now, which are still developing, such as in Bayan and Lingsar.
\end{abstract}

Keywords: History, Islamization, Lombok.

Abstrak Tulisan ini mendiskripsika sejarah perkembangan Islam di Lombok pada abad ke-17, menunjukkan bahwa Pulau Lombok merupakan salah satu tempat penyebran Islam yang di lakukan oleh Sunan Prapen dari Jawa Timur. Sejarah penyebaran Islam sangat menarik untuk dikaji di wilayah tersebut karena beberapa bangunan menunjukkan telah terjadinya penyebaran Islam sangat cepat. Sejak Islam masuk ke pulau Lombok yang dimulai sekitar abad ke-17 M, di bawa dari Sulawesi Selatan, dan disebarkan melalui pulau Sumbawa. Pasca kedatangan agama Islam belum maksimal diterapkan ajarannya di pulau Lombok. Demikian terlihat pada perkembangan ajaran Islam waktu Lima dan ajaran Islam Waktu Telu sampai saat ini masih berkembang seperti di Bayan dan Lingsar.

Kata Kunci: Sejarah, Islamisasi, Lombok. 


\section{A. PENDAHULUAN}

Sejarah perkembangan Islam di Indonesia, sebagaimana kita ketahui secara umum lebih banyak membicarakan wilayah bagian barat saja, terutama pulau Jawa atau pulau-pulau besar lainnya (Sumatra, Kalimatan, Sulawesi), sedangkan wilayah bagian timur Indonesia tidak begitu banyak yang membahasnya. Akibat dari itu semua, pengetahuan mengenai bangsa Indonesia akan menjadi berat sebelah dan karenanya sulit mengerti bangsa Indonesia secara keseluruhan, maka timbullah ketimpangan-ketimpangan yang memprioritaskan pusat dan menelantarkan daerah (Haris, 2005).

Indonesia bagian timur terdapat jejeran pulau-pulau kecil (Bali, Lombok, Sumbawa, Kupang, dan lain-lain) yang memiliki sejarah yang hamper sama dengan apa yang dialami pulau-pulau bagian barat. Atas dasar "senasip dan seperjuangan" maka pulau-pulau kecil itu pun bergabung dalam negara kesatuan yang dinamakan Indonesia, meksipun dalam sejarahnya mereka memiliki background birokrasi kerajaan (patrimonial). Pulau Lombok misalnya memiliki sejarah yang begitu dinamis, ia dikuasai lima pengusa yang datang berurutan. Kerajaan Majapahit menjadi penguasa pertama, dilanjutkan oleh Kesultanan Makassar, lalu Kerajaan Kareng Asem Bali, kemudian colonial Belanda dan terakhir adalah Dai Nippon (Jepang) (Budiwanti, 2000).

Jika kita telisik lebih mendalam peristiwa pada abad ke-16 hingga peristiwa yang masuk sampai pada abad ke-17, pulau-pulau Lombok menjadi primadona perdagangan internasional, bermula ketika datangnya Portugis ke wilayah Nusa Tenggara Timur (NTT) berlanjut dengan datangnya Belanda di Bali, Lombok, dan Sumbawa (Pamarimatha, 2002). ketertarikan akan pulau-pulau kecil itu pun akhirnya berubah menjadi penjajahan. Sejalan dengan masuknya para penguasa di atas, Pulau Lombok juga diwarnai dengan masuknya pengaruh Islam yang dibawa dari Makassar dan pulau Jawa terutama Jawa Timur, baik melalui perdagangan maupun penguasaan (Haji Lalu Wacana, 1548-1606). Padaabadke-17, Islam di Lombok dibawa oleh Sunan Prapen (anak dari Sunan Ratu Giri) yang mengakibatkan gesekangesekan langsung maupun tak langsung dengan budaya yang sudah mapan di pulau itu (Hindu dan Budha Majapahit).

Penelitian tentang "Sejarah Perkembangan Islam di Pulau Lombok pada abad ke-17", merupakan bentuk keberadaan Agama Islam yang dianut sampai sekarang oleh masyarakatnya. Agama Islam yang 
berkembang di Pulau Lombok meninggalkan berbagai macam bentuk bangunan salah satunya yang ada di Pulau Lombok Bagian Utara atau Kabupaten Lombok Utara khusunya di Desa Bayan terdapat Masjid Bayan yang diketahu didirikan sekitar pada abad ke-15.

Untuk itu ada beberapa pokok masalah yang difokuskan dalam penelitian ini, yaitu: (1) bagimana sejarah kedatangan Islam di Pulau Lombok, (2) bagaimana metode penyebaran dan ajaran Islam di pulau Lombok, dan (3) bentuk varian-varian keagamaan dan organisasiorganisasi Islam di Pulau Lombok.

\section{B. PEMBAHASAN}

\section{Islam di Lombok Abad ke-17 Masehi}

Islam di Lombok pada dasarnya merupakan hasil kontak perdagangan para pedagang muslim dengan berbagai kerajaan di Indonesia pada abad ke-13 hingga abad ke-14. Secara umum, Islam masuk dan berkembang di Lombok dilakukan oleh dua kelompok Islam yaitu kelompok Islam Esoteris yaitu tokoh Islam dari dalam Pulau Lombok itu sendiri, sebelum adanya modernisasi dan transportasi ibadah haji, setelah adanya modernisasi transportasi ibadah haji. Pada saat itu Islam masuk dan berkembang di Lombok pada abad ke-15 dan ke-16, Islam disebarkan para tokoh Tuan Guru dari kalangan Islam Esoteris atau orang dari dalam Lombok sendiri, atau yang dinamakan Islam Sufi. Pada masa itu pada abad ke-17, mubalig yang menyebarkan agama Islam di Lombok adalah para pedagang muslim dari luar Lombok yang datang berdagang melalui pelabuhan Lombok, seperti pedagang dari Pulau Jawa, Palembang, Banten, Gresik, dan Sulawesi (Ariadi, 2013; Fauzan, 2018)

Periodesasi Penyebaran Islam di Lombok Abad Ke-17 M. Secara historis, perkembangan Islam di Pulau Lombok menjadi kuat setelah raja Lombok melakukan kerjasama dengan kerajaan Makasar. Dan penaklukan yang di hasilkan oleh sultan Makasar (Gowa) atau raja Lombok (Dewa Maharaja Parawa) pada tahun 1623 menyebabkan kontak antara raja-raja Lombok, dan raja Makasar (sudah masuk agama Islam tahun 1603). Pada tahun 1650 disebutkan bahwa seluruh penduduk Pulau Lombok memeluk agama Islam (Manca, 1984). Pendatang baru yang datang darai luar Pulau Lombok kemudian di kenal sebagai orang yang benar-benar yang mau menetap di wilayah Pulau Lombok, dan bagi pendatang ke Lombok di namakan dalam bahasa Sasak yaitu Tetun atau Belu yang artinya, orang yang diduga telah datang 
ke timor pada abad ke-14, mula-mula di dataran rendah Benain (kini daerah kefetoran Wehali).

Hal itu sangat mungkin terjadi sesudah penaklukan Malaka oleh Portugis (1511). Pada masa itu, wilayah Nusa Tenggara sudah dikenal sebagai penghasil kayu cendana. Namun, migrasi dari Malaka tetap belum jelas, miskipun orang-orang di Pulau Lombok percaya apa yang disampaikan lewat tradisinya (Parimartha, 2002).

Secara eksplisit, dewasa ini belum ada kajian yang mendalam tentang kedatangan Islam di Lombok pada abad ke-17 M, tetapi, setidaknya ada tiga teori yang menjelaskan tentang masuknya Islam di Lombok, yaitu: Pertama Islam masuk ke Lombok pada abad ke-13 M, bersamaan dengan masuknya para pedagang Gujarat ke Perlak, Samudera Pasai, juga dari Arab, yaitu adanya seseorang mubaligh Syaihk Nurul Rasyid yang kemudian menikah dengan dende bulan (Dewi Anjani) dan melahirkan anak bernama Zulkarnain, yaitu cikal bakal Raja Selaparang. Di Batu Layar, kota Mataram terdapat makam seorang Arab bernama Syaid Duhri Haddab al Hadami yang mengembangkan Islam pada masa kerajaan Selaparang di Pulau Lombok juga sudah diketahui sejak abad ke 17. M (Ariadi, 2013).

Teori kedua menjelaskan bahwa Islam di Lombok dibawa dari Jawa oleh Sunan Perapen (1548-1605) putra Sunan Giri atau yang lebih dikenal dengan Sunan Ratu Giri keempat, datang bersama dengan Pangeran Sangapati pada abad ke-16, Melalui jalan utara, hal ini ditandai dengan adanya Lokal Jawa, Ampel Duri, dan Ampel Gading di Bayan Lombok Utara melalui pelabuhan Carik, Anak Agung Ketut Agung, menyebutkan bahwa penyebaran Islam mulai dari Kerajaan Lombok sebelah Timur, kemudian menyebar ke kerajaan tetangga lainnya, seperti Kerajaan Langko, Kerajaan Pejanggik, Kerajaan Bayan, Kerajaan Parwa, Kerajaan Sarwadadi, Kerajaan Sokong dan Kerajaan Sasak (Anak Agung Ketut Agung, 1661-1950). Teori Ketiga menyebutkan bahwa Islam masuk ke Lombok pada abad yang sama, yakni abad ke-16, namun melalui jalur Timur, yakni dari pulau Sumbawa yang kemudian disebarkan oleh para pedagang dan pelaut dari Makasar. Sebagaimana diketahui, Kerajaan Selaparang Islam Semula di Labuan Lombok, Kabupaten Lombok Timur yang kemudian sekarang di pindahkan ke bekas ibukota Kerajaan Selaparang Hindu, yaitu Waktu perang Lombok. Dan Teori yang ketiga ini adalah sebagaimana Islam di Bima yang datang dari Makasar dan kemudian menuju Lombok (Jamaluddin, 2004). 
Dari ketiga teori tersebut dapat disimpulkan bahwa Islam masuk di Pulau Lombok pada abad ke-16 dan berkembang pesat sampai abad ke17,dua di antara ketiga teori masuknya Islam di Pulau Lombok menegaskan hal tersebut, yakni dari dua jalur (arah) yang berbeda yaitu dari arah Barat yaitu Jawa dan dari arah Timur yaitu dari Makasar melewati Bima dan Sumbawa baru kemudian ke Pulau Lombok, walaupun tidak dapet menutup mata juga dari teori yang pertama (Syakur, 2013).

Raden Paku belajar di Ampel bersama dengan Sunan Bonang. Ketika keduanya berniat akan pergi haji maka terlebih dahulu keduanya berhenti di Malaka dan bertemu dengan Wali Lanang. Jadilah keduanya santri Wali Lanang selama setahun. Dalam pertemuan dengan Wali Lanang inilah keduanya diberi julukan. Raden Paku dengan julukan Prabu Satmata dan Sunan Bonang dengan julukan Prabu Nyakrakusumadi. Keduanya diperintahkan untuk pulang ke Ampel Denta. Keduanya berperan dalam Proses Islamisai di Tuban dan Gresik. Daerah dakwah Sunan Giri bahkan sampai ke Pulau Lombok, Makasar, Maluku, Halmahera, dan Tarnate. Sunan Giri menurunkan sejumlah auliya dan raja-raja local yang kelak baru dapat ditundukkan oleh kerajaan Mataram semasa Amangkurat. Bahkan menurut cerita terdapat 6000 santri dari Giri yang dibunuh di alun-alun Plered semasa pemerintahan Amangkurat I, Raja Mataram (Syam, 2013).

Pada abad ke-16 hingga abad ke-17, kontak antara para pedagang dengan masyarakat Sasak berubah menjadi media para muballig atau dari Tuan Guru, dalam menyebarkan Islam ke masyarakat Sasak. Melalui ajaran-ajaran Islam yang bernuansa sufistikmengakulturasikan semangat spiritual keagamaan masyarakat Sasak yang ada dalam filosofi Sasak Lombok' dengan spiritual keagamaan yang ada dalam Rukun Islam, terutama ibadah Haji. Muncul dan berkembangnya Islam pada masyarakat Sasak terkait dengan dua hal, yaitu pengaruh kedatangan Islam dengan ajaran-ajaran sufistiknya, dan akulturasi semangat spiritual agama-agama lokal di masyarakat pulau Lombok dengan spiritual yang ada dalam ibadah haji yang di lakukan oleh orang Lombok.

Masyarakat Sasak mengenal sosok seorang tokoh Islam yang bernama Habib Husein bin 'Umar al-Masyhur Marzaq, atau yang lebih dikenal dengan nama Habib Husein. Seorang ulama Arab yang berasal dari Tarim, Hadralmaut. Bersama Habib Abdullah Shahab, Tuan Guru menyebarkan Islam di Lombok pada abad ke-17. Melakukan perjalanan 
dakwahnya dari Hadralmaut ke Kalikut, India, lalu ke Aceh, dan ke Pulau Lombok. Saat melakukan dakwah Islam di Lombok, Habib Husein diminta oleh Raja Lombok untuk mengobati Tuan Putri yang sedang sakit. Setelah Ia menyembuhkan Tuan Putri, Habib Husein meminta dihadiahkan tanah di Bintaro. Oleh Habib Husein, tanah ini dihibahkan untuk tanah tempat pemakaman orang- orang Islam yang meninggal (Ariadi, 2013).

Periode Bali-Lombok dengan berbagai cara di bawah kekuasaan raja Bali sejak tahun 1640. Pengaruh orang-orang Bali pada kepercayaan dan praktek Islam di Lombok mungkin sangat signifikan, miskipun seberapa luasnya pengaruh itu sulit ditentukan dengan pasti. Contohnya dari pengaruh orang-orang Bali yang paling mungkin, dapat dilihat dalam singkretis IslamWetu Telu yang praktek-praktek dan sistem kulturalnya tampaknya menyerupai praktek kosmologi orang-orang Bali dalam beberapa hal. Namun demikian, tidaklah jelas apakah ini karna pengaruh langsung dari orang-orang Bali atau karna kenyataan bahwa keduanya berasal dari Jawa yaitu kerajaan Majapahit. Bahwa banyak daerah dari kalangan masyarakat Wetu Telu sebagian besar terisolasi dari kontrak orang-orang Bali yang membawa praktek-praktek yang menyerupai praktek-praktek agama orang Bali mengesankan kemungkinan penjelasan yang lebih lanjut (Bartholomew, 2001).

Pengaruh Penyebaran Islam Terhadap Perilaku Keberagaman Masyarakat Sasak di Lombok. Penganut agama Boda diperkirakan telah ada di Pulau Lombok pada sekitar abad ke-16 M. Fakta ini berdasarkan penemuan empat buah Arca Perunggu di Batu Pandang, Desa Sapit, Kecamatan Pringgabaya, Kabupaten Lombok Timur pada tahun 1634. Selain dikenal dengan nama Agama Boda, agama ini dikenal dengan istilah yang lain, yaitu Bodha Budhi. Penganut agama Bodha di Lombok dalam mengangkat pengikut Budha tidak membedakan pangkat dan kedudukannya. Mereka tidak membedakan kasta dan golongan. Karna adanya doktrin ini, agama Budha yang menyebar di Pulau Lombok lebih dikenal oleh masyarakat Lombok, sebagai agama Bodha atau Budha Budhi (Ariadi, 2013).

Adapun mereka yang mengalami proses Islamisasi dengan sempurna digolongkan sebagai penganut Islam Waktu Lima, sebagaimana Islam yang umumnya dikenal luas. Mereka diidentikkan dengan orang-orang Islam yang secara taat dan sempurna melaksanakan ajaran agamanya, seperti shalat, zakat, puasa, haji dan sebagainya. Jumlahnya merupakan 
mayoritas umat beragama dan tersebar hampir di seluruh bagian pulau Lombok (Ariadi, 2013).

Berbeda halnya dengan IslamWaktu Lima, penganut IslamWaktu Telu, diidentikkan dengan mereka yang dalam peraktek kehidupan sehari-hari sangat kuat pegangannya kepada adat-istiadat nenek moyang mereka. Dalam ajaran Waktu Telu, terdapat banyak nuangse Islam didalamnya. Namun demikian, artikulasinya lebih dimaknakan dalam idiom adat. Pada masa itu warna agama bercampur dengan adat, padahal adat sendiri tidak selalu sejalan dengan aturan agama. Pencampuran praktek-praktek agama ke dalam adat ini menyebabkan watak Waktu Telu menjadi sangat singkretik (Ariadi, 2013).

Beberapa kalangan yang melihat fenomena Waktu Telu dalam makna yang samadengan penganut Islam abangan di kalangan masyarakat Jawa. Akan tetapi, dilihat dari konsepsi serta cara pandang masingmasing, tidaklah tepat untuk mempersamakan antara keduanya. Menurut Zamakhsyari Dhofier, Islam abangan hanya merupakan sebutan bagi orang Islam yang tidak taat melaksanakan ajaran Islam. Dan secara lebih rinci Abdul Jabbar Adlan-sebagaimana dikutip Syamsuddinmengidentifikasi Islam Abangan sebagai kelompok yang (Geertz, 1999).

Pertama, Tidak melakukan atau jarang melakukan syariat Islam dengan alasan belum sempat, miskipun mereka mengakui itu semua adalah kewajiban agama Islam. Kedua, masih melakukan semua yang sudah dilarang agama walupun mereka mengakui bahwa hal-hal tersebut dilarang agama. Ketiga, mempunyai keinginan melaksanakan syariat dan meninggalkan larangan syara' bila sudah tua.

Berbeda dengan Waktu Telu, bagi mereka Waktu Telu adalah bentuk akhir dari keberagamaan, yang tidak akan beranjak menujuWaktu Lima. Apabila ada di kalangan penganut Waktu Telu yang akhirnya memutuskan untuk menganut Waktu Lima, perubahan keyakinan ini merupakan konversi (perpindahan) agama, bukan sebuah pencapaian menuju derajat keberagamaan yang lebih tinggi. Dengan berpegang dengan alasan ini, jelas terdapat perbedaan yang signifikan diantara keduanya (Madjid, 2004).

\section{Varian Islam di Pulau Lombok}

Varian Islam waktu telu dan waktu lima, varian islam waktu telu sudah ada sekitar abad ke-1650 akibat proses pengislaman atau dakwah Islam pada masa awal kedatangan Islam abad ke-17 di Pulau Lombok. Para 
pemeluk agama Islam Waktu Telu ini masih sangat terpengaruh oleh kepercayaan yang dianut sebelumnya, yaitu animisme dan budhisme. Di samping juga kurang sempurnanya pembinaan keimanan dan ketakwaan mereka, mengingat sangat kurangnya kesempatang muballig dalam membina mereka. Keadaan ini menghasilkan sengkretisme antara kepercayaan mereka sebelum datangnya Islam dengan kepercayaan keislaman yang diajarkan para Tuan Guru.Dengan kata lain, ajaran Islam yang diterima/diterapkan mereka masih belum sampurna dan belum murni (Ahyar, 1996).

Ketidakmurnian penerapan ajaran Islam ini kemungkinan terjadi akibat ditinggalkannya masyarakat Sasak yang baru memeluk agama Islam tersebut oleh para mubalig yang mengajarkannya menuju ketempat lain untuk keperluan yang sama. Padahal pada saat itu masyarakat Sasak tersebut masih berada dalam masa transisi antara ajaran Islam dan kepercayaan lama mereka. Karana kurangnya pendidikan di kalangan masyarakat Sasak atau pada saat itu, mereka tidak mau menerima ajaran Islam selain dari guru atau mubalig yang pertamakali mengajarkan agama tersebut dan yang dipercayainya. Akibatnya, pengetahuan mereka tentang ajaran Islam pun sangat terbatas, hanya yang mereka terima dari mubalig pertama, tanpa ada usaha lain untuk lebih menyempurnakan secara intensif melalui para mubalig Islam lain yang datang sesudah itu. Dampak dari keterbatasan pengetahuan mereka ini, lahirnya varian Islam Wetu Telu (Islam Waktu Tiga) (Ahyar, 1996).

Pertama, Wetu Telu lahir sebagai konsekuensi dari strategi dakwah yang di terapkan oleh para penyebar agama Islam, setelah melihat sulitnya media dakwah dengan adanya penolakan-penolakan dari dan tingginya fanatisme masyarakat Sasak yang menganut Hinduisme dan Budhisme (Budiwanti, 2000). Kedua, Asal-usul Wetu Telu adalah dua para pangeran Sangopati, salah seorang penyebar agama Islam di Lombok. Dalam sebuah Babad yang tertulis di atas daun lontar disebutkan bahwa tokoh ini mempunyai dua putra, Nurcahaya dan Nursada. Nurcahaya digambarkan sebagai pendiri WetuLima dan Nursada digambarkan sebagai pendiri Watu Telu. Yany pertama digambarkan sebagai muslim yang ortodok dan puritan, sementara yang terakhir sebagai muslim yang tradisional dan singkretik (Ahyar, 1996).

Ketiga, Wetu Telu lahir sebagai akibat dari usaha Belanda dalam mewujudkan pertentangan antara kaum muslimin. Setelah menguasai 
pulau Lombok pada tahun 1894, Belanda berusaha mencari taktik untuk bisa menguasai orang-orang Sasak selaku penganut Islam Wetu Lima. Untuk itulah diciptakanlah Islam Wetu Telu (Pendidikan dan Kebudayaan, 1983). Keempat, Wetu Telu muncul karna adanya program penghinduan yang dilakukan oleh seorang pendande bernama Dangkian Niraka yang dikirim oleh Raja Gelgel dari Bali pada tahun 1530. Pendande tersebut dengan cerdiknya meramu ajaran Animisme, Dinamisme, Hindu, Buddha dan Islam yang merupakan kepercayaan lama masyarakat, sehingga merupakan Singkretisme dari agama-agama atau kepercayaan-kepercayaan tersebut. Proses penghinduan ini semakin gencar dilakukan, terutama ketika raja Gusti Nengah dari kerajaan Karangasem Bali menaklukkan kerajaan Selaparang sekitar tahun 1630 M(Budiwanti, 2000).

\section{Islam Waktu Lima}

Masyarakat Sasak adalah mayoritas penganut Islam Waktu Lima. Wajah Islam Waktu Limasama halnya dengan Islam yang ada di luar Lombok. Islam Waktu Lima muncul sebagai perbandingan dari Islam Waktu Telu. Islam Waktu Lima menjalankan ajaran agama sesuai dengan ajaran AlQur'an dan Hadis Nabi terutama dalam aqidah, syari'ah, muammalah dan akhlaq. Penganut Islam Waktu Lima mayoritas merupakan masyarakat Sasak yang dapat dikatakan kelompok Islam tradisionalis dan modernis yang tergabung dalam organisasi sosial keagamaan yang terkenal dalam kalangan Islam Waktu Lima (Syakur, 2013).

Jika dilihat dari segi perkembangan sejarah masuknya mazhab Syafi'i terdapat beberapa pendapat seperti menurut Fathur Rahman (Zakaria, 1998). Islam berkembang di Lombok sekitar abad ke-17 M. Tetapi dalam pandangan Ahmad Abd. Syakur abad ke-17 Islam telah berkembang pesat dibawah oleh para Tuan Guru yang telah kembali dari tanah suci Makkah setelah kembali belajar ilmu-ilmu agama di Makkah. Sehingga masuknya Islam pertama kali ke pulau Lombok sekitar abad ke-17 M (Syakur, 2013).

Pada akhir abad ke-17 kebebasan dan kemerdekaan masyarakat Sasak telah hancur dan kembali mendapatkan angin segar miskipun tidak dengan sepenuhnya. Awal sampai akhir abad ke-17 masyarakat Sasak berada dalam genggaman penjajahan Belanda dan Jepang. Miskipun masyarakat Lombok dalam genggaman Kolonel Belanda dan Jepang, mereka tidak kemudian menghalangi para Tuan Guru untuk 
menjalankan ibadah seperti naek haji dan tentunya pendidikan telah didapatkan oleh masyarakat Sasak (Majid, 2008). Pada awal abad ke-17 sekitar tahun 1600 pemerintah Belanda baru mendirikan beberapa lembaga pendidikan yang sifatnya formal yaitu pendidikan dasar hal tersebut adalah bagian dari politik etis yang di layangkan. Beberapa lembaga yang didirikan yaitu HIS (Hollandsch Indlandsche School) yang berlokasi di Mataram, sekolah dasar Bumi Putra yang berbahasa Belanda (Muliadi, 2015).

Hadirnya para Tuan Guru sebagai pendidik mengantarkan masyarakat Sasak kedalam setuasi yang lebih tercerahkan. Sebagaian Tuan Guru mengembara menuntut Ilmu ke tanah suci Makkah sepulangnya membuka beberapa tempat-tempat pengajian dan sebagianya bagi yang belum mendirikan pondok pesantren, mereka menempati Masjid, Musalla, dan rumah kiyai. Dalam catatan Sejarah salah satu sebagai tokoh pembaruan pendidikan Islam pada abad ke1620 saat itu adalah TGH Zainudin Abdul Majid (Muliadi, 2015).

Dalam menganalisis kepercayaan dan praktek keagamaan Waktu Telu, teradisi keagamaan Waktu Lima juga disajikan di sini sebagai latar belakang dan bahan perbandingan mengenai bagaimana seharusnya Islam dipraktekkan dari sudud pandang kitab sucinya sendiri. Karna Waktu Lima relatif lebih banyak menggunakan standar ideal Islam sebagai patokan, maka mereka melihat dalam berbagai kepercayaan dan peribadatan Waktu Telu terjadi penyimpangan dan pelanggaran yang fundamental. Pandangan yang mereka pakai untuk melihat penyimpangan-penyimpangan tersebut, dari sudut pandang kitab suci sebagaimana yang tertulis dalam Al-Qur'an dan hadis, juga menjadi salah satu isu sentral yang dibicarakan dalam bab ini.

Mayoritas Waktu Lima berpandangan bahwa kurang sempurnanya model peribadatan Islam di kalangan orang Waktu Telu untuk sebagaian di sebabkan karna mereka benar-benar terbenam dalam praktekpraktek adat mereka, terutama pelistarian praktek-praktek kuno pemujaan leluhur yang diturunkan dari satu generasi ke generasi berikutnya, yang sarat dengan animisme.

Dalam pandangan Waktu Lima, sebutan Waktu Telu dengan demikian tidak cuma terkait dengan kurangnya praktek baku Islam, tetapi dengan adanya sebagian kemiripannya dengan agama Hindu. Sebutan itu dikontraskan oleh Waktu Lima atau Orang Islam yang 
mengikuti secara jauh lebih ketat ajaran-ajaran Islam sebagaimana di tetapkan Al-Qur'an dan Hadis.

Sesungguhnya identitas Waktu Telu tidak hanya dilekatkan oleh golongan Waktu Lima kepada orang Sasak asli di Bayan saja, melainkan kepada orang Sasak yang tinggal di tempat-tempat lain di kabupaten Lombok Barat, seperti Kecamatan Narmada dan Tanjung. Orang Waktu Telu di Desa Lingsar, Kecamatan Narmada, berbagai pura dengan orang Hindu Bali. Setiap tahun kelompok-kelompok tersebut merayakan Perang Ketupat sampai sekarang mansih dilakukan dalam rangka mensyukuri keberhasilan panen dengan saling melempar pake ketupat (Budiwanti, 2000).

Antopologi Geertz dalam bukunya yang berjudul The Religion of Java Hasil penelitiannya mengungkapkan tentang bagaimana masyarakat Indonesia, khususnya pada masyarakat Jawa terbagi dalam tiga varian. Penggolongan penduduk tersebut berdasarkan kepercayaan keagamaan, prefrensi etis dan idiologi politik orang-orang Jawa menghasilkan tiga tipe utama kebudayaan mencerminkan organisasi moral kebudayaan Jawa sebagaimana dicerminkan di Mojokuto, dalam kebudayaan orang Jawa telah berkembang tiga (3) tipologi agama. Ketiga tipologi tersebut baginya memiliki karakteristik yang satu sama lain yaitu Islam abangan, Islam santri dan Islam priyayi(Geertz, 1983).

Sistem keberagamaan dan varian sosial yang dijelaskan di atas, pada masyarakat perkotaan cendrung berjalan normal dan sangat toleran, sehingga jarang sekali didapati komflik-komflik yang singnifikan antara pengikut organisasi tertentu dengan komunitas yang lain. Ada pendapat yang menyatakan bahwa pola yang baik ini hadir dikarnakan oleh implikasi kesamaan sosio-politik masyarakat Sasak dan ketiadaan agensi idiologis maupun pretensi sosio-kultural yang berakibat pada kenderungan bagi orang Sasak untuk mengurangi sebanyak mungkin perbedaan-perbedaan di antara mereka (Bartholomew, 2001).

Dari asumsi diatas, maka dapat dikatakan bahwa dalam realitas keberagamaan masyarakat Sasak pun akan didapatkan kenyataan seperti agama masyarakat Jawa. Realitas keberagamaan dalam masyarakat Sasak dikenal dengan varian Islam Wetu Telu. 


\section{KESIMPULAN}

Perkembangan Islam di Lombok abad ke-17 M, merupakan perkembangan keagamaan yang didukung oleh beberapa faktor. Faktor ajaran yang mudah diterima sebagaimana tergambar dalam proses masuknya Islam ke pulau Lombok terjadi dengan cara damai pada abad ke-17, miski mendapat respon yang berbeda dari masyarakat Lombok, tapi dari mayoritas masyarakat Lombok menerima kedatangan Islam dengan baik. Pengikut Islam mulai berkembang pesat yang terutama disebarluaskan oleh para Tuan Guru melalui media pendidikan. Seperti pondok pesantren dan organisasi-organisasi Islam. Varian Islam yaitu Islam Waktu Telu dan Islam Waktu Lima. Keduanya sama-sama percaya adanya Allah swt, dan bahwa Muhammad SAW, adalah utusan Nabi atau Rasul-nya.

\section{DAFTAR PUSTAKA}

Agung, A. A. K. 1991. Kupu-kupu Kuning Yang Terbang di Selat Lombok: Lintasan Sejarah Kerajaan Karangasem, 1661-1950 (Denpasar: PT Upada Sastra.

Ahyar, M. 1996. Etika Merarik Pada Masyarakat Muslim Waktu Telu di Bayan Lombok Utara, (Yogyakarta: IAIN Sunan Kalijaga, Skripsi.

Ariadi, L. M. 2013. Haji Sasak: Sebuah Potret Dialektika Haji dan KebudayaanLokal. Ciputat: IMPRESSA Publishing.

Bartholomew, J. R. 2001. Alif Lam Mim: Kearipan Masyarakat Sasak, terj. Imron Rosyadi. Yogyakarta: Tiara Wacana.

Bartholomew, J. R. 2001. Alif Lam Mim: Kearipan Masyarakat Sasak, terj. ImranRosyidi.Jogjakarta: Tiara Wacana.

Budiwanti. 2000. Islam Sasak "Wetu Telu Versus Watu Lima". Yogyakarta: LKiS.

Departemen Pendidikan dan Kebudayaan, Derektorat Jenderal Kebudayaan. 1983. Geografi Budaya Daerah Nusa Tenggara Barat. Jakarta: Departemen Pendidikan dan Kebudayaan RI.

Fauzan, A. (2018). Sistem Pertukaran Orang Sasak dalam Prosesi Sorong Serah Ajikrame. SANGKéP: Jurnal Kajian Sosial Keagamaan,1(1), 29-48.

Geertz, C. 1983. Abangan, Santri, Priyayi: Dalam Masyarakat Jawa Jakarta: Pustaka Jaya. 
Geertz, C. 1983. Abangan, Santri, Priyayi: Dalam Masyarakat Jawa. Jakarta: Pustaka Jaya.

Geertz, C. 1999. After The Fack: Dua Negeri Empat Dasawarsa Satu Antropolog. Yogyakarta: LKiS.

Haris, S. 2005. Desentralisasi dan Otonomi Daerah. Jakarta: Yayasan Obor Indonesia.

Jamaluddin, 2004. Islam Sasak: Sejarah Sosial Keagamaan di Lombok (abad XVI-XIX) (Jakarta: UIN Syarif Hidayatullah Jakarta.

Madjid, Z. A. 2004. Visi Kebangsaan Religius Refleksi Pemikiran dan Perjuangan. Cakung: Jakarta.

Majid, D. 2000. Berhaji di Masa Kolonial.Jakarta: CV Sejahtra, 2008.

Manca, L. 1984. Sumbawa Pada Masa Lalu: Suatu Tinjauan Sejarah. Surabaya: Rinta.

Pamarimatha. I. G. 2002. Perdagangan dan politik di Nusa Tenggara 1815-1915, Jakarta: KTILV.

Parimartha, G. L. 2002. Perdagangan dan Politik di Nusa Tenggara. Jakarta: Djambatan.

Syakur, A. A. 2006. Islam dan Kebudayaan Akulturasi Nilai-Nilai Islam dalam Kebudayaan Sasak (Yogyakarta: PT Adab Press).

Syakur, M. A. 2013. Islam dan Kebudayaan Muhammad Ariadi, Haji Sasak, Sebuah Potret Dialektika Haji dan Kebudayaan Lokal (Ciputat: IMPRESSA Publishing.

Syam, N. 2013. Tarekat Petani Fenomena Tarekat Syatariyah Lokal. Yogyakarta: LKIS Press.

Zakaria. F. 1998. Mozaik Budaya Mataram. Mataram: Yayasan Sumurmas Al- Hamidy. 
